\title{
STUDIES IN ASCORBIC ACID WITH ESPECIAL REFERENCE TO \\ THE WHITE LAYER. I. DESCRIPTION OF METHOD AND COMPARISON OF ASCORBIC ACID LEVELS IN WHOLE BLOOD, PLASMA, RED CELLS, AND WHITE LAYER ${ }^{1,2}$
}

\author{
By ROSE LUBSCHEZ \\ (From the New York Hospital and the Department of Pediatrics, \\ Cornell University Medical College, New York City)
}

(Received for publication January 8, 1945)

Considerable data have accumulated on ascorbic acid levels in blood plasma (1), but reported data on the level of ascorbic acid in the white cellplatelet layer are limited ( 1 to 4 ). This is due to technical difficulties and to the quantity of blood required for a single determination. Estimations of ascorbic acid in whole blood have also been advocated as a means of reflecting the level in the white cell-platelet layer (6). Data on the relationship between the ascorbic acid level in the red cells and the plasma have also been presented $(2,7,8)$.

In this study, a relatively simple method is presented which permits analysis of ascorbic acid levels in whole blood, plasma, red cells, and white layer in a single $4.5 \mathrm{ml}$. specimen of venous blood, together with analyses of ascorbic acid concentrations in whole blood, plasma, red cells, and white cell layer.

\section{A. METHODS}

Roe and Kuether have developed a method of high specificity and sensitivity for determining the ascorbic acid content of whole blood and plasma. The method depends upon the coupling of 2,4 dinitrophenylhydrazine with dehydroascorbic acid (9). In this study, the Roe method has been modified to permit analysis of small samples of blood and it has also been applied to measurements of the white layer.

\section{Reagents}

All reagents were prepared and used as outlined by Roe and Kuether with the following exceptions:

A fresh 10 per cent solution of trichloroacetic acid in distilled water was prepared daily. Sulfuric acid solution was prepared by adding 7 volumes of concentrated acid to 3 volumes of distilled water. The acid was stored in

1 This work was aided by a special grant from the Commonwealth Fund.

2 The assistance of Dr. Otto Bessey and Dr. Oliver Lowry is gratefully acknowledged. the refrigerator and added to the colorimeter tubes by pipette, without the use of an ice bath. After preparing acid washed norit as outlined by Roe, a 5 per cent suspension in distilled water was made up. The small particles that floated on the surface were removed by drawing a piece of coarse filter paper over the surface of the liquid.

\section{Collection and preparation of blood specimens}

Fasting venous blood ( $4.5 \mathrm{ml}$.) is collected in a dry tube containing Wintrobe's double oxalate mixture, ${ }^{3}$ taking care to avoid hemolysis. Five-tenths of a ml. of blood is measured into a centrifuge tube and set aside for the analysis of whole blood. The remaining $4 \mathrm{ml}$. of blood are pipetted into a constricted centrifuge tube, ${ }^{*}$ the top covered by a small square of parafilm, and the tube is centrifuged at 3000 r.p.m. for 30 minutes.

After transfer of $0.5 \mathrm{ml}$. of plasma into a centrifuge tube for analysis, the remainder of the plasma is poured off. The constricted tube is again centrifuged for at least 2 additional hours at 3000 r.p.m. to insure complete packing and separation of the white layer. During the last half hour of centrifugation, the small amounts of plasma which collect above the white layer are drawn off with slow suction until no more plasma is seen above the white layer. The white layer is now clearly divided into 2 approximately equal portions, an upper creamy white layer and a lower pinkish gray layer,-the upper layer containing about 95 per cent platelets and 5 per cent leukocytes by count and the lower layer containing predominantly leukocytes with some platelets in its uppermost portion and many red cells in its lowest portion (2).

\footnotetext{
${ }^{3}$ Ammonium oxalate, 1.2 per cent, and 0.8 per cent potassium oxalate, mixed; $0.1 \mathrm{ml}$. is used per $\mathrm{ml}$. of blood, measured into the collection tube by pipette and evaporated to dryness in the oven.

4 These tubes, patterned after those designed by Butler and Cushman (2), are calibrated to contain $4 \mathrm{ml}$. The bulb volume is $1 \mathrm{ml}$., the capillary portion contains $1 \mathrm{ml}$, and the cup volume is $2 \mathrm{ml}$. The white layer of any blood specimen whose hematocrit ranges from 25 to 50 per cent will fall within the capillary portion. These tubes are available on special order from E. R. Machlett and Son, N. Y.
} 
After the white layer is drawn off, it is weighed. The remaining column of cells in the capillary section of the tube is removed with suction and the red cells are drawn up from the bottom of the tube by pipette $;^{5} 0.5 \mathrm{ml}$. of red cells is transferred to a centrifuge tube for analysis, using a pipette calibrated to contain, with subsequent rinsing.

\section{Analysis of whole blood and plasma}

To $0.5 \mathrm{ml}$. of whole blood or plasma, measured into a centrifuge tube with an Ostwald-Folin pipette, $1 \mathrm{ml}$. of 10 per cent trichloroacetic acid is added and the contents stirred with a glass rod until all of the protein is precipitated. Five-tenths of a $\mathrm{ml}$. of norit suspension is then added and the contents of the tube thoroughly mixed. The tube is stoppered and centrifuged at 1000 r.p.m. for 15 minutes. After centrifugation, $0.8 \mathrm{ml}$. of the supernatant liquid is drawn off and transferred to a colorimeter tube, ${ }^{6}$ one drop of thiourea solution is then added, followed by $0.2 \mathrm{ml}$. of a freshly filtered solution of phenylhydrazine reagent. The contents are mixed by shaking and incubated for 3 hours, as outlined by Roe. Following incubation, $1 \mathrm{ml}$. of a cold 70 per cent (by volume) solution of sulfuric acid is pipetted into the tube and the contents thoroughly mixed. The tube is read in the colorimeter after standing a half hour.?

\section{Analysis of red cells}

For red cell determinations, the procedure is identical, except that $0.5 \mathrm{ml}$. of distilled water is used to rinse 0.5 $\mathrm{ml}$. of red cells pipetted into a centrifuge tube, $2 \mathrm{ml}$. of trichloroacetic acid are added, and $1 \mathrm{ml}$. of norit suspension, making the final dilution $1: 8$ instead of $1: 4$.

\section{Analysis of the white layer}

For white layer, determinations, the entire upper portion is drawn up into a capillary pipette about $0.9 \mathrm{~mm}$. in diameter. The cells are delivered into a weighed dry centrifuge tube by blowing through a tube plugged with non-absorbent cotton. The weight of the white layer is obtained by difference. For adequate analysis, a specimen of at least $5 \mathrm{mgm}$. is desirable. Immediately following weighing, $0.25 \mathrm{ml}$. of distilled water is pipetted into the tube and the cells are laked thoroughly by rubbing up with a glass rod. At this stage, the cells should appear to be uniformly suspended in the water. After standing one hour, $80.5 \mathrm{ml}$. of trichloroacetic acid is added, the

\footnotetext{
5 Capillary pipettes of varying sized bores were drawn from ordinary glass tubing. These were used for filling the constricted tubes, drawing off the white layer, and drawing off the red cells.

- This step is facilitated by the use of a constricted Lang-Levy pipette.

7 Any photoelectric colorimeter accommodating $2 \mathrm{ml}$. of final solution may be used. A Coleman Junior spectrophotometer was used in the majority of these studies.

8 An alternative procedure is to freeze the suspension quickly in dry ice, thaw, and proceed with the analysis.
}

contents mixed, and again mixed following the addition of $0.25 \mathrm{ml}$. of norit suspension. The tube is centrifuged, $0.8 \mathrm{ml}$. of the supernatant liquid is drawn off, and treated as previously outlined.

The blank used is $0.8 \mathrm{ml}$. of a 5 per cent solution of trichloroacetic acid previously shaken with norit and filtered, one drop of thiourea, and $0.2 \mathrm{ml}$. of the phenylhydrazine reagent, incubated with the specimen tubes, acidified, and read after a half hour.

A standard solution of $0.0025 \mathrm{mgm}$. per $\mathrm{ml}$. of ascorbic acid in 5 per cent trichloroacetic acid, corresponding to a diluted plasma specimen of $1.0 \mathrm{mgm}$. per cent, is analyzed once a week for obtaining a $\mathrm{K}$ value for the colorimeter, as outlined by Mindlin and Butler (10). The $\mathrm{K}$ value is used to check a curve of ascorbic acid concentrations from which the ascorbic acid content of the specimens is computed. It was found that within the galvanometer range used for the analysis ( $G$ ranged from 70 to 95 ), a single concentration of standard was sufficient.

\section{Comment}

The modifications made in the Roe method permit the analysis of whole blood, plasma, red cells, and white layer by an identical chemical procedure. The use of norit suspension, with the elimination of the filtration step in the original method made it possible to use smaller specimens at optimum dilutions.

Tests have shown that the norit suspension must be added after protein precipitation. If the norit suspension is added to plasma prior to trichloroacetic acid, the values obtained are lower by about $0.2 \mathrm{mgm}$. per cent than those obtained by Roe's original procedure. As outlined, the use of norit suspension yields results identical to those obtained in the original procedure.

Comparative plasma determinations using the modified Roe method and the Mindlin and Butler indophenol method agree with $\pm 0.2 \mathrm{mgm}$. per cent in specimens analyzed within 2 to 3 hours following collection (Table I).

The determination of red cell levels by this method cannot be considered consistently reliable since some difficulty was encountered in measuring the volume of packed red cells accurately, and in some of the tubes containing red cell filtrates turbidity developed during incubation which was diluted but not removed by subsequent acidification. Transient turbidity was occasionally noted in the tubes containing whole blood filtrates. Turbidity was never noted in the tubes containing plasma or white cell filtrates. 
TABLE I

Comparison of plasma levels obtained using the Mindlin and Butler and Roe methods

Mindlin and Butler
0.2
0.3
0.3
0.3
0.4
0.4
0.5
0.6
0.8
0.9
0.9
1.0
1.0
1.1

$\begin{array}{lc}\text { Roe } & \text { Difference } \\ 0.3 & +0.1 \\ 0.3 & \\ 0.5 & +0.2 \\ 0.3 & \\ 0.3 & -0.1 \\ 0.2 & -0.2 \\ 0.6 & +0.1 \\ 0.5 & -0.1 \\ 0.8 & +0.2 \\ 1.1 & -0.2 \\ 0.7 & -0.2 \\ 0.8 & +0.2 \\ 1.0 & \end{array}$

A most important step in white layer determinations is the complete extraction of ascorbic acid from the cells. The cells should be allowed to stand in water for about one hour following laking and before protein precipitation. An alternative procedure is to freeze the cell suspension quickly, by standing the tube in dry ice. It was found that thawed cell suspensions, or those analyzed following one hour of soaking in water, yield values from 5 to 25 per cent higher than untreated cell suspensions.

When the cells have been extracted completely, there is no difference in the ascorbic acid levels of the platelet and leukocyte layers $(2,4)$. Specimens which include the lowest portion of the leukocyte layer, and which consequently contain many red cells, have been found to be about 40 per cent lower than the upper layer. For consistent results, care must be taken to avoid the introduction of red cells from the lowest portion of the white layer into the specimens. Hemolysis must be avoided throughout the collection and preparation of blood specimens, so that the white layer is clearly defined. A sample smaller than 5 mgm. is not applicable to this method. When a capillary pipette of about $0.9 \mathrm{~mm}$. diameter is used to draw up the specimen, the lowest portion of the white layer is not disturbed, and the specimen is removed with ease.

This method for determining the level of ascorbic acid in the white layer would appear to offer an advantage over previous methods, since the chemical procedures are more easily adaptable to routine use. Of particular advantage is the fact that a $4 \mathrm{ml}$. specimen of blood is adequate for analysis, in contrast to the 10 to $12 \mathrm{ml}$. speci- men used by Butler and Cushman. Duplicate plasma and whole blood determinations gave identical results, as did aliquot specimens of white layer suspensions. The method appears to be completely reliable for making single determinations, which is a distinct advantage in routine procedures.

The determination of the white layer ascorbic acid level by this method has the practical disadvantage that about 6 hours are required for the completion of the analysis. This is due to the $2 \frac{1}{2}$ hour period of centrifugation and the 3 hours of incubation required. It was found that the weighed white cells may be stored overnight in a vacuum bottle containing dry ice, either dry, in water suspension, or in water and trichloroacetic acid, with no loss of ascorbic acid. Whole blood and plasma may be treated similarly. Specimens may therefore be stored frozen until a convenient time for completion of the analysis.

\section{B. COMPARISON OF THE LEVELS OF ASCORBIC ACID in WHOle blOOD, PlASMA, RED CELls,}

\section{AND WHITE LAYER ${ }^{9}$}

These studies include 167 comparative analyses for 99 individuals. With the exception of 29 studies on 17 adults who were members of the house and nursing staffs of the New York Hospital, all of whom were in apparent good health, the remaining 82 subjects, on whom 138 studies were made, were children between the ages of 2 and 14 years. Thirty-eight of these were ambulatory patients attending the out-patient pediatric clinics at the New York Hospital and 44 were convalescent non-febrile children on the pediatric pavilions. When several specimens of blood were taken from the same individual, the interval of time between specimens varied from days to weeks.

On the adult subjects and the pavilion patients, fasting morning blood specimens were taken. Specimens were taken from the clinic patients 2 to 3 hours following a breakfast which included no fruit of any kind nor tomato juice. All specimens were therefore fasting specimens or their equivalent with respect to vitamin $\mathrm{C}$.

In an attempt to determine the relationship

\footnotetext{
$9 \mathrm{We}$ are indebted to the resident staff and the nursing service for their cooperation.
} 
between the ascorbic acid levels in the various blood elements, plasma levels were compared to whole blood and red cell levels. In addition, a range of white layer levels in children was determined and the white layer levels were correlated with the plasma levels.

\section{Comparison of whole blood and plasma levels}

In 63 comparative determinations, it was found that the majority of the whole blood values were greater than the plasma values, with an average difference of $0.14 \mathrm{mgm}$. per cent. This difference between plasma and whole blood levels may be accounted for by the small contribution of the white cells in the whole blood specimen. The relation between plasma and whole blood values was not different at different levels, and the average whole blood levels parallel the curve of plasma levels. Since the experimental error in all available methods approximates $0.1 \mathrm{mgm}$. per cent, there would seem to be no advantage in making whole blood determinations in conjunction with or as a substitute for plasma determinations. The presence of a variable amount of red cells in dif- ferent specimens did not appear to affect the whole blood values significantly (Figure 1).

\section{Comparison of plasma and red cell levels}

It has already been stated that the occasional development of turbidity during incubation may render the method used unreliable for red cell determinations. There were, however, 46 comparative determinations of red cell and plasma levels in which turbidity was absent. In these, it was observed that a majority of the red cell values were lower than the plasma values, with an average difference of $0.20 \mathrm{mgm}$. per cent. The average red cell values parallel the curve of plasma levels. This trend is consistent with other observations (2). The determination of red cell levels does not offer additional information with regard to tissue concentration of ascorbic acid, and the presence of red cells in the whole blood specimens may counterbalance the effect of the white cells in whole blood analyses (Figure 2).

\section{Range in white layer levels}

Butler and Cushman (4) reported a normal range in the white layer level of from 25 to 43

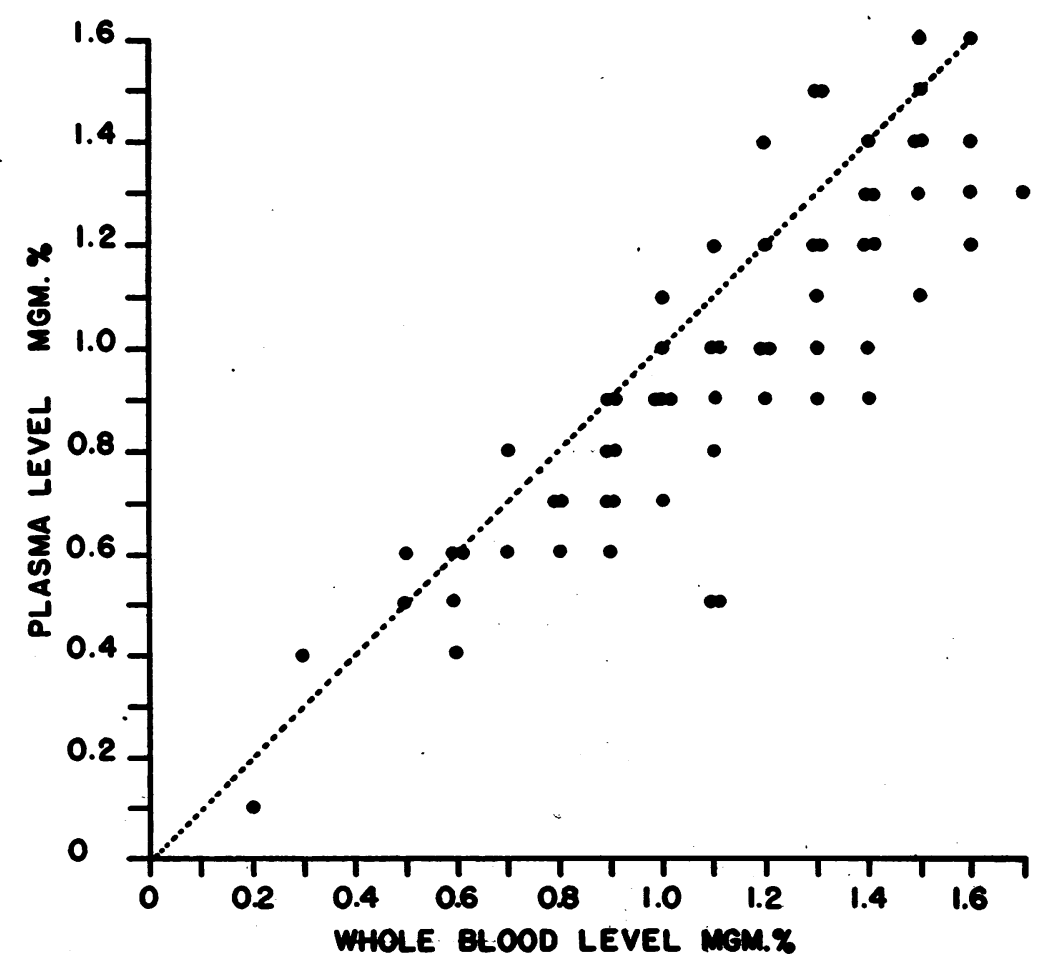

Fig. 1. Comparison of Whole Blood and Plasma levels of Ascorbic Acm 


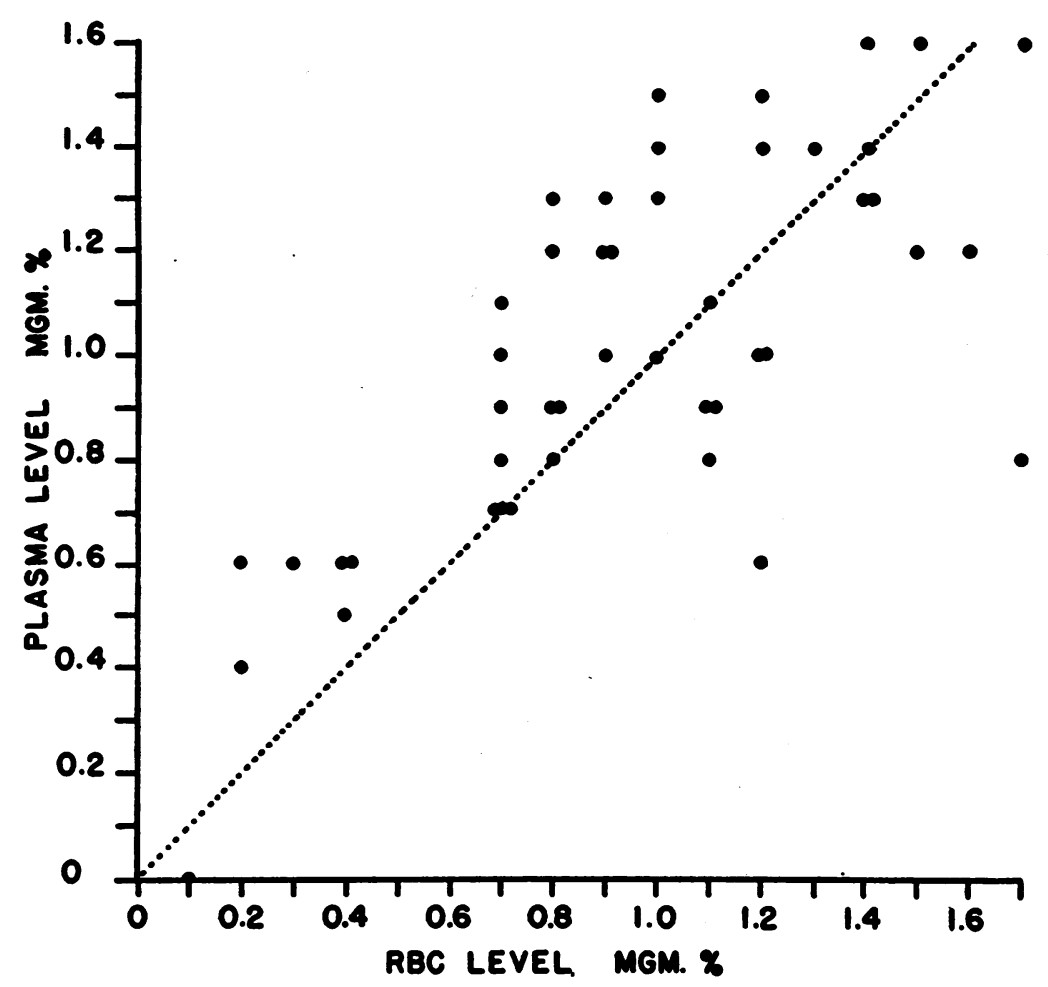

Fig. 2. Comparison of RBC and Plasma Levels of Ascorbic Acid

mgm. per 100 grams leukocytes in a small series of determinations made on normal adults. The range found in 50 white layer determinations made on 48 children between the ages of 2 and 14 years extended from 6 to $58 \mathrm{mgm}$. per 100 grams leukocytes with the majority of the determinations falling between 11 and $30 \mathrm{mgm}$. per 100 grams leukocytes. Five determinations made on normal adults fell between 13 and $38 \mathrm{mgm}$. per 100 grams leukocytes.

\section{Comparison of plasma and white layer levels}

It was found that the majority of the children having plasma levels below $0.7 \mathrm{mgm}$. per cent had white layer levels in the lowest range. No subject having a plasma level below $0.7 \mathrm{mgm}$. per cent had a white layer level above 30 . However, those having the highest plasma levels did not have the highest white layer levels, and at the lower plasma levels, there were relatively high white layer levels (Figure 3 ). Thus, as might be expected from previous studies (2 to 5), it appears that although there is a greater chance for the white layer level to be high if the plasma level is high, there is not a direct correlation.

\section{Comment}

Fasting specimens or those taken after a vitamin C-free breakfast were used throughout these studies. It was noted in 4 well nourished adult subjects, whose fasting plasma levels ranged from 0.5 to $0.9 \mathrm{mgm}$. per cent, that following a test dose of $100 \mathrm{mgm}$. of ascorbic acid, the plasma level rose 0.2 to $0.5 \mathrm{mgm}$. per cent, representing an increase of about 40 per cent in a 3 -hour period. The white layer levels, which ranged from 15 to 35 mgm. per 100 grams leukocytes, increased 1 to 4 mgm., representing an increase of about 15 per cent. This would indicate that a fasting specimen is preferable for white layer determinations.

The correlation between dietary intake and ascorbic acid levels in the plasma and white layer is now under investigation. The range in white layer levels revealed in this study may be interpreted to reflect variable but probably low intakes in a non-febrile clinic population.

\section{CONCLUSIONS}

The method of Roe and Kuether for determining the ascorbic acid content of whole blood and 


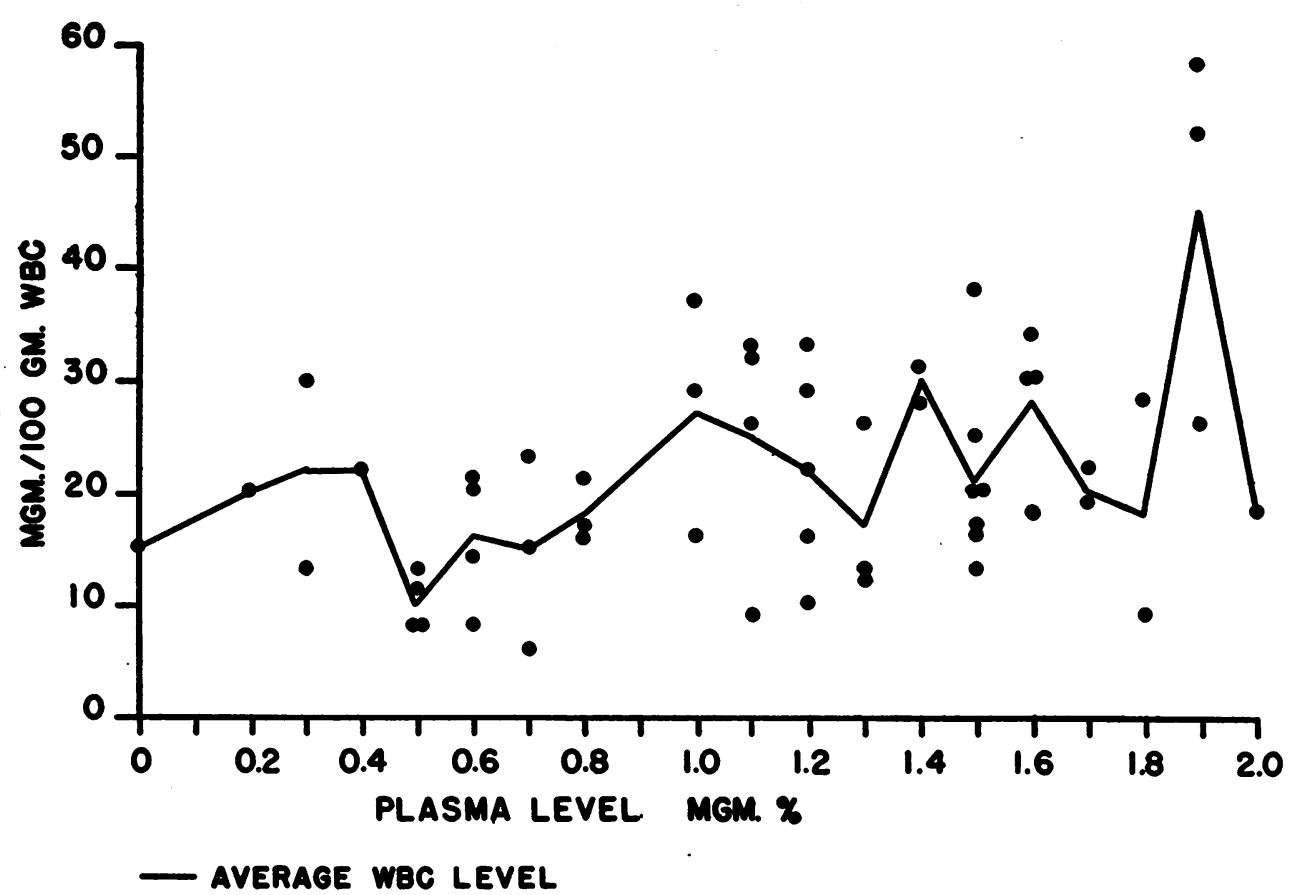

Fig. 3. WBC Levels at Different Plasma Levels of Ascorbic Acid

plasma has been modified for routine use on small specimens of whole blood, plasma, and the white layer, the entire procedure requiring a single 4.5 $\mathrm{ml}$. specimen of venous blood.

The determination of red cell levels by this method is not consistently reliable, due to occasional technical difficulty.

A comparison of whole blood, plasma, and red cell determinations made on specimens of fasting blood, indicates that the whole blood and red cell determinations provided no specific additional information beyond that gained by the plasma determinations.

The range in white layer levels in a series of ambulatory, non-febrile clinic children whose intake was unknown, but probably low, was found to be from 6 to $58 \mathrm{mgm}$. per 100 grams leukocytes, with the majority falling between 11 and 30 .

No direct correlation was observed between the fasting plasma level and the white layer level. At high plasma levels, the highest and the lowest white layer levels were found.

\section{BIBLIOGRAPHY}

1. Ralli, E. P., and Sherry S., Adult scurvy and metabolism of vitamin C. Medicine, 1941, 20, 251.
2. Butler, A. M., and Cushman, M., Distribution of ascorbic acid in the blood and its nutritional significance. J. Clin. Invest., 1940, 19, 459.

3. Crandon, J. H., Lund, C. C., and Dill, D. B., Experimental human scurvy. New England J. Med., 1940, 223, 353.

4. Butler, A. M., and Cushman, M., An ascorbic acidlike reducing substance in the buffy layer of centrifuged oxalated blood. J. Biol. Chem., 1941, 139, 219.

5. Pijoan, M.; and Lozner, E. L., Vitamin C economy in the human subject. Bull. Johns Hopkins Hosp., 1944, 75, 303.

6. Butler, A. M., Cushman, M., and MacLachlan, E. A., Determination of ascorbic acid in whole blood and its constituents by means of methylene blue; macroand micromethods. J. Biol. Chem., 1943, 150, 453.

7. Heinemann, M., Distribution of ascorbic acid between cells and serum in relation to urinary excretion. J. Clin. Invest., 1938, 17, 751.

8. Heinemann, M., Distribution of ascorbic acid between cells and serum of human blood. J. Clin. Invest., 1941, 20, 39.

9. Roe, J. H., and Kuether, C. A., Determination of ascorbic acid in whole blood and urine through 2,4-dinitrophenylhydrazine derivative of dehydroascorbic acid. J. Biol. Chem., 1943, 147, 399.

10. Mindlin, R. L., and Butler, A. M., Determination of ascorbic acid in plasma; a macromethod and micromethod. J. Biol. Chem., 1938, 122, 673. 